\title{
Financial Systems Theory: \\ Banker-Customer Relationship and Nigerian Deposit Money Banks' Performance: An Empirical Investigation
}

\author{
OLOKOYO FELICIA ${ }^{1}$, ISIBOR AREGHAN ${ }^{2}$, ADEGBOYE FOLASADE $^{3}$, ADESINA TOLULOPE $^{4}$, \\ OSUMA GODSWILL ${ }^{5}$, and ADEBAYO MERCY ${ }^{6}$ \\ Covenant University ${ }^{1,2,3,4,5,6}$ \\ Canaan Land, Km 10 Idiroko Road, Ota, Ogun State \\ NIGERIA
}

Abstract:- In today's competitive banking environment, quality service is critical to individual Deposit Money Banks' success. Delivering high quality service is closely linked to profit, cost, savings, and increasing market share. The major aim of this research is to examine the relationship that exists between Deposit Money Banks and their customers based on the challenges the banks are facing while giving quality service delivery. A sample size of 328 staffs of four selected banks was determined using the Yamane formula. The result showed that there is a positive and significant link between Deposit Money Banks' performance and bank-customer relationship. This study therefore recommends among others that Deposit Money Banks should put more efforts in rendering good services to their customers.

Keywords: Financial Systems, Financial Systems' Theory, Control of Finances, Banker-Customer Relationship, Bank Performance, Quality Service, Banking Environment

Received: January 9, 2020. Revised: June 30, 2020. Re-revised: September 17, 2020. Accepted: October 8, 2020. Published: October 22, 2020.

\section{Introduction}

The customer is the center of attraction to all activities in the banking industries both in Nigeria and all over earth. Banking is the only service sector attributed by high customer service, where customer satisfaction is the ultimate goal. The efficient banking performance is a sign of financial stability and this can only happen if the relationship between the banks and their customers is positive [3]. According to [1], providing good services is necessary for growth and development in today's financial system. The bank performance depends largely on its relationship with its customers. [2] opined that knowing how companies can grow from their customer services is vital for the growth of firms. In the banking sector, the way banks relate with their customers can affect the bank's performance positively or negatively. Any different banks performance would be as a result of decline in their relationship with their customers.

The Nigerian banking industry has become more competitive in recent time. [5] stressed that the more the customer base of a bank, the more the profit of such bank and if the knowledge of a bank in the aspect of customer service is broad, banks would have a good relationship with its customer thereby enhancing its performance. Customers are seen as kings in every aspect of business and are to be treated as such. However, some bank customers are not treated with such respect and this has brought about unhealthy business relationship between banks and their customers due to poor manner of approach [6]. In recent times, banks were associated with slow pace of service as a result of undue documentations and long queues. In some cases, to even obtain a cheque 
booklet is characterized by long delay and most times some bank workers exhibit poor attitude to work. Other problems faced include - frauds perpetrated by bank staffs and customers and so on. The emergence of new channels and technologies such as the mobile banking, internet banking also has significantly altered how banks communicate with customers [7].

The study thus wants to examine the relationship between Deposit Money Banks and their customers based on the challenges the banks are facing while giving quality service delivery.

This study intends to look at various ways in which good banker-customer relationship can be fostered. It also seeks to address issues that affect the performance of Nigerian banks through customers' relationships.

\section{Conceptual Review}

Bank- customer relationship is basically a contract between creditor and debtor. As the customer puts money in his account and his account is credited, the customer becomes creditor to the bank and the bank becomes debtor to customer. The reverse is the case when the customer takes credit or overdraft. Relationship could be expressed in different forms such as; Debtor and Creditor, Pledger and Pledgee, Licensor and Licensee, and so on. Termination of the bank-customer relationship can also occur in different ways which include; a written agreement to close the account, termination by act of law such as death, mental illness, etc. Receipt of garnishee order is a court ruling attaching the credit balance of a customer to stop an account. In case of death, the account of such customer would automatically terminate and the balance transferred to the customer personal representative.

\subsection{Banker-Customer Relationship}

In Foley vs. Hill 1848, a banker-customer relationship was described as an implied term [2]. That is once a customer goes to the bank to open an account, it is implied that a banker customer relationship is about to take place. The implied terms are:

1. When a bank receives money e.g. cash, cheques etc from a customer, it means a banker customer relationship is established.

2. When a bank does not act as an agent or trustee.

3. When it is the duty of the banker to pay on demand to its customers during banking hours.

4. A customer has the right to demand for payment when he has sufficient funds in his account and when there is no legal bar to the payment.

5. The bank is to charge reasonable interest for the services rendered to the customer.

\section{Design of Research}

The research used qualitative and quantitative design under survey method in the presentation of data gathered through structured questionnaires. A total of four (4) banks - First Bank, GTBank, UBA, and Zenith bank Plc were purposively picked based on their size and asset base. Two sets of questionnaires were distributed to the employees (managerial and non-managerial) of the banks on one hand and to their customers on the other hand. The sample size for this 
study consists of three hundred and ninety-five (395) respondents which were derived using the Yamane's formula. The data was analyzed using the correlation analyses.

The SPSS package was used to run the analysis, used to conduct study using the Kruder Richardson or Cronbach alpha reliability test which was positive at .703 values.

\subsection{Hypothesis of Research}

$\mathrm{H}_{0}$ : There exists no significant impact of bankcustomer relationship on performance of banks.

\section{Analysis of Data}

\subsection{Reliability Statistics}

Table 1: Alpha Value

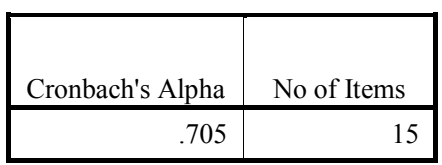

A total numbers of 395 questionnaires were distributed based on sample size. The Cronbach's Alpha figure of 0.703 implies that the research instrument is reliable enough for generalization of findings and policy implications.

\subsection{Analysis of Data}

Table 2: When Did You Start Using the Bank?

\begin{tabular}{|c|l|l|l|l|l|}
\hline \multicolumn{2}{|c|}{} & Freq & $\%$ & Valid \% & Cumulative\% \\
\hline Valid & 1-5years & 174 & 53.0 & 53.0 & 53.0 \\
\cline { 2 - 6 } & 6-10years & 119 & 36.3 & 36.3 & 89.3 \\
\cline { 2 - 6 } & $\begin{array}{l}\text { 11years } \\
\text { and Above }\end{array}$ & 35 & 10.7 & 10.7 & 100.0 \\
\cline { 2 - 6 } & Total & 328 & 100.0 & 100.0 & \\
\hline
\end{tabular}

The result implies that the many respondents just started operating with their various banks because majority of the respondent range between 1-5years.
Table 3: What Attracted You to Joining such

\section{Banks?}

\begin{tabular}{|l|l|r|r|r|r|}
\hline \multicolumn{2}{|c|}{} & \multicolumn{1}{|c|}{ Freq } & \multicolumn{1}{l|}{$\begin{array}{l}\text { Valid } \\
\%\end{array}$} & $\begin{array}{l}\text { Cumulative } \\
\%\end{array}$ \\
\hline Valid & Advertisement & 96 & 29.3 & 29.3 & 29.3 \\
\cline { 2 - 6 } & $\begin{array}{l}\text { Products and } \\
\text { Services }\end{array}$ & 119 & 36.3 & 36.3 & 65.5 \\
\cline { 2 - 6 } & $\begin{array}{l}\text { Recommendation } \\
\text { from friends and } \\
\text { relatives }\end{array}$ & 82 & 25.0 & 25.0 & 90.5 \\
\cline { 2 - 6 } & Others & 31 & 9.5 & 9.5 & 100.0 \\
\cline { 2 - 6 } & Total & 328 & 100.0 & 100.0 & \\
\hline
\end{tabular}

The table above shows that majority were attracted through products and services. This means that the bank has improve its product and services.

\section{Table 4: How is Your Relationship With}

\section{Customers/Bank?}

\begin{tabular}{|ll|r|r|r|r|}
\hline & \multicolumn{1}{|l|}{ Freq } & \multicolumn{2}{|l|}{$\begin{array}{l}\text { Valid } \\
\%\end{array}$} & Cumulative \% \\
\hline Valid & Fairly & 17 & 5.2 & 5.2 & 5.2 \\
& Good & 136 & 41.5 & 41.5 & 46.6 \\
& Very & 119 & 36.3 & 36.3 & 82.9 \\
Good & 56 & 17.1 & 17.1 & 100.0 \\
Excellent & 328 & 100.0 & 100.0 & \\
Total & &
\end{tabular}

The table reveals the customers and staff have a good relationship with each other. This would create a positive relationship with the customer.

Table 5: How Does Your Relationship Affect Banks Performance?

\begin{tabular}{|c|c|c|c|c|c|}
\hline & & Freq & $\%$ & $\begin{array}{l}\text { Valid } \\
\%\end{array}$ & Cumulative \% \\
\hline \multirow[t]{6}{*}{ Valid } & Poorly & 1 & .3 & .3 & .3 \\
\hline & Fairly & 28 & 8.5 & 8.5 & 8.8 \\
\hline & Good & 140 & 42.7 & 42.7 & 51.5 \\
\hline & Very Good & 130 & 39.6 & 39.6 & 91.2 \\
\hline & Excellent & 29 & 8.8 & 8.8 & 100.0 \\
\hline & Total & 328 & 100.0 & 100.0 & \\
\hline
\end{tabular}


Table 5 shows bank-customer relationship affect bank's performance in a good way but it can be improved in other to correct the $0.3 \%$ poor relationship.

Table 6: Bankers Are Polite In Their Dealings With Customers

\begin{tabular}{|ll|r|r|r|r|}
\hline & \multicolumn{1}{|l|}{ Freq } & \multicolumn{2}{l|}{$\begin{array}{l}\text { Valid } \\
\%\end{array}$} & \multicolumn{2}{l|}{$\begin{array}{l}\text { Cumulative } \\
\%\end{array}$} \\
\hline Valid & SD & 2 & .6 & .6 & .6 \\
& D & 10 & 3.0 & 3.0 & 3.7 \\
U & 18 & 5.5 & 5.5 & 9.1 \\
A & 198 & 60.4 & 60.4 & 69.5 \\
SA & 100 & 30.5 & 30.5 & 100.0 \\
Total & 328 & 100.0 & 100.0 & \\
\hline
\end{tabular}

Result above shows that majority agree that a banker is polite in their dealings with customers.

Table 7: Atmosphere for Positive Customer Relationship Is Created In The Banking Hall

\begin{tabular}{|ll|r|r|r|r|}
\hline & Freq & \multicolumn{1}{c|}{$\%$} & $\begin{array}{c}\text { Valid } \\
\%\end{array}$ & Cumulative \% \\
\hline Valid & SD & 2 & .6 & .6 & .6 \\
& D & 8 & 2.4 & 2.4 & 3.0 \\
& U & 20 & 6.1 & 6.1 & 9.1 \\
A & 210 & 64.0 & 64.0 & 73.2 \\
SA & 88 & 26.8 & 26.8 & 100.0 \\
Total & 328 & 100.0 & 100.0 & \\
\hline
\end{tabular}

Result above reveals banking hall creates an atmosphere for positive bank customer relationship because the majority of the respondents agree to it although few disagree to it.
Table 8: Your Bank Follows the Principle Of Customer Is The 'King'

\begin{tabular}{|c|c|c|c|c|c|}
\hline & & Freq & $\%$ & $\begin{array}{l}\text { Valid } \\
\%\end{array}$ & $\begin{array}{c}\text { Cumulative } \\
\%\end{array}$ \\
\hline \multirow[t]{6}{*}{ Valid } & SD & 1 & .3 & .3 & .3 \\
\hline & $\mathrm{D}$ & 20 & 6.1 & 6.1 & 6.4 \\
\hline & $\mathrm{U}$ & 47 & 14.3 & 14.3 & 20.7 \\
\hline & A & 172 & 52.4 & 52.4 & 73.2 \\
\hline & SA & 88 & 26.8 & 26.8 & 100.0 \\
\hline & Total & 328 & 100.0 & 100.0 & \\
\hline
\end{tabular}

Banks actually follow the principle of customer is the king although some persons disagree to this facts but majority agree. One of the duties of a bank to its customers is to treat the customer as a 'king' to ensure continuity of operations of such customer in their bank.

Table 9: Customers Approach Bank Staff Politely.

\begin{tabular}{|ll|r|r|r|r|}
\hline & Freq & \multicolumn{1}{c|}{$\%$} & $\begin{array}{c}\text { Valid } \\
\%\end{array}$ & $\begin{array}{c}\text { Cumulative } \\
\%\end{array}$ \\
\hline Valid & SD & 5 & 1.5 & 1.5 & 1.5 \\
& D & 40 & 12.2 & 12.2 & 13.7 \\
U & 64 & 19.5 & 19.5 & 33.2 \\
A & 165 & 50.3 & 50.3 & 83.5 \\
SA & 54 & 16.5 & 16.5 & 100.0 \\
Total & 328 & 100.0 & 100.0 & \\
\hline
\end{tabular}

It is seen that customer approach to bank staff is actually polite because the majority of the respondents agreed to it. When customers approach bank staff politely, the staff attending to that customer at that particular time would respond to the customer politely too and it would enhance a cordial relationship between the staff and customer. 
WSEAS TRANSACTIONS on SYSTEMS and CONTROL DOI: $10.37394 / 23203.2020 .15 .54$
Table 10: Inability of Banks To Grant Long-Term Credit Facilities To Their Customers Will Not Create An Effective Banker-Customer Relationship

\begin{tabular}{|rl|r|r|r|r|}
\hline & \multicolumn{1}{|c|}{ Freq } & \multicolumn{1}{c|}{$\%$} & \multicolumn{1}{c|}{$\begin{array}{c}\text { Valid } \\
\%\end{array}$} & $\begin{array}{c}\text { Cumulative } \\
\%\end{array}$ \\
\hline Valid & SD & 10 & 3.0 & 3.0 & 3.0 \\
& D & 25 & 7.6 & 7.6 & 10.7 \\
U & 80 & 24.4 & 24.4 & 35.1 \\
A & 152 & 46.3 & 46.3 & 81.4 \\
& SA & 61 & 18.6 & 18.6 & 100.0 \\
Total & 328 & 100.0 & 100.0 & \\
\hline
\end{tabular}

Inability of banks to grant long term credit facilities to their customers will not create effective bankercustomer relationship because majority of the respondents agree. Most banks' customers are business owners who might need medium to longterm credit facilities to help with the operations of their businesses, if such wish is not granted by their banks, the customer might not continue to transact with such bank. Such customers might want to transact business with another bank that grants their request.

\section{Table 11: Banker-Customers Relationships Have}

\section{Effect on The Bank Performances}

\begin{tabular}{|ll|r|r|r|r|}
\hline & \multicolumn{1}{|c|}{ Freq } & \multicolumn{1}{c|}{$\%$} & \multicolumn{1}{c|}{$\begin{array}{c}\text { Valid } \\
\%\end{array}$} & $\begin{array}{c}\text { Cumulative } \\
\%\end{array}$ \\
\hline Valid & D & 4 & 1.2 & 1.2 & 1.2 \\
& U & 31 & 9.5 & 9.5 & 10.7 \\
& A & 168 & 51.2 & 51.2 & 61.9 \\
& SA & 125 & 38.1 & 38.1 & 100.0 \\
& Total & 328 & 100.0 & 100.0 & \\
\hline
\end{tabular}

Banker-customer relationships have great impact on banks performances. Positive relationship among banks and its customers would increase operations in the bank there by increasing the bank's performance.
Table 12: Inability of Customers To Pay Their Debts When Due Will Create a Negative Impact On Their Relationship With The Bank

\begin{tabular}{|c|c|c|c|c|c|}
\hline & & Freq & $\%$ & $\begin{array}{l}\text { Valid } \\
\%\end{array}$ & $\begin{array}{c}\text { Cumulative } \\
\%\end{array}$ \\
\hline \multirow[t]{5}{*}{ Valid } & $\mathrm{D}$ & 8 & 2.4 & 2.4 & 2.4 \\
\hline & $\mathrm{U}$ & 25 & 7.6 & 7.6 & 10.1 \\
\hline & A & 183 & 55.8 & 55.8 & 65.9 \\
\hline & SA & 112 & 34.1 & 34.1 & 100.0 \\
\hline & Total & 328 & 100.0 & 100.0 & \\
\hline
\end{tabular}

Inability customers to pay back their debts as at when due will bring about a negative impact on their relationship with the bank. If a customer fails to pay back his/her debt as at when due, the bank would be reluctant to issue another credit facility if asked for.

Table 13: Your Relationship Serves As a Tool Inenhancing Banks Performance

\begin{tabular}{|rl|r|r|r|r|}
\hline & \multicolumn{1}{|l|}{ Freq } & \multicolumn{2}{l|}{$\begin{array}{l}\text { Valid } \\
\%\end{array}$} & \multicolumn{2}{l|}{$\begin{array}{l}\text { Cumulative } \\
\%\end{array}$} \\
\hline Valid & D & 7 & 2.1 & 2.1 & 2.1 \\
& U & 52 & 15.9 & 15.9 & 18.0 \\
A & 185 & 56.4 & 56.4 & 74.4 \\
SA & 84 & 25.6 & 25.6 & 100.0 \\
Total & 328 & 100.0 & 100.0 & \\
\hline
\end{tabular}

A positive relationship between bank staff and their customer can help boost the performance of the bank.

Table 14: Indecent Behavior by Bank Staff To Customer Will Create A Bad Relationship Between The Bank And Its Customer

\begin{tabular}{|ll|r|r|r|r|}
\hline & \multicolumn{1}{|c|}{ Freq } & \multicolumn{1}{c|}{$\%$} & \multicolumn{1}{c|}{$\begin{array}{c}\text { Valid } \\
\%\end{array}$} & $\begin{array}{c}\text { Cumulative } \\
\%\end{array}$ \\
\hline Valid & SD & 2 & .6 & .6 & .6 \\
& D & 14 & 4.3 & 4.3 & 4.9 \\
U & 52 & 15.9 & 15.9 & 20.7 \\
A & 177 & 54.0 & 54.0 & 74.7 \\
SA & 83 & 25.3 & 25.3 & 100.0 \\
Total & 328 & 100.0 & 100.0 & \\
\hline
\end{tabular}

Indecent behavior by bank staff to customer will create a bad relationship because majority of 
WSEAS TRANSACTIONS on SYSTEMS and CONTROL DOI: $10.37394 / 23203.2020 .15 .54$ respondents agree. If a bank staff behaves rudely to a customer, the customer may not want to continue to bank with such bank.

\subsection{Hypotheses Testing}

$\mathrm{H}_{0}$ : No significant impact of bank-customer relationship on bank performance.

\section{Table 15: Correlation Coefficients}

\begin{tabular}{|ll|l|l|}
\hline & & $\begin{array}{l}\text { Bank } \\
\text { customer } \\
\text { relationship }\end{array}$ & $\begin{array}{l}\text { Bank } \\
\text { Performance }\end{array}$ \\
\hline $\begin{array}{l}\text { Bank customer } \\
\text { relationship }\end{array}$ & Pearson Correlation & 1 & $.688(* *)$ \\
& Sig. (2-tailed) & & .000 \\
Performance of & Pearson Correlation \\
bank & Sig. (2-tailed) & 328 & 328 \\
& $\mathrm{~N}$ & $.688\left(^{* *}\right)$ & 1 \\
& .000 & 328 \\
\hline
\end{tabular}

\section{Coefficient of the Determination (COD)}

$$
\begin{aligned}
\text { C.O.D } & =\mathrm{R}^{2} \times 100 \\
& =(0.688)^{2} \times 100 \\
& =0.4733 \times 100 \\
& =47.33 \%
\end{aligned}
$$

Where $\mathrm{R}=$ Pearson Correlation 0.688

Correlation is significant at level 0.01(2-tailed)

Correlation figure of 0.688 shows that the relationship between the bank-customer positively and significantly affects banks performance, which means bank-customer relationship explains $47.33 \%$ of the variance in the respondents scores. The correlation ( $\mathrm{r}$ $=0.688^{* *}$ ) between banks-customers relationship and banks performance is highly and positively significant at 0.01 level, thus the null hypothesis is rejected.

\section{Recommendations}

It is a fact still that not all customers can be totally satisfied because all customers are not the same. However, the banks should put more effort at engendering good relationship with their customer who in turn will enhance customer loyalty and trust. More so, customers are becoming more sophisticated due to the available information on disposal. Therefore, banks should try their possible best to ensure that customers are satisfied to the maximum and their complaints are treated with immediate effect. They should ensure transactions are carried out in orderly manner and the bank's staff should also grant customers full attention, excellent customer service and also good services and products as these are very critical to banks performance.

\section{References:}

[1] Abora, D. (2011). The Impact of Quality Customer Service on the Performance of Some Selected Banks in Kumasi Metropolis, Unpublished Thesis. Accessed on March 29, 2016, available at ir.knust.edu.gh:8080/handle/123456789/4496

[2] Adiele, K. C. and Gabriel, J. M. O. (2013). Customer Relationship Management and Bank Performance in Nigeria: An Empirical Validation Study, International Journal of Science an Research, Vol. 2, No.1, pp. 416-421.

[3] Akin, I., Ikpefan, O.A., and Isibor, A.A. (2019). Credit to the private sector and economic growth in the present technological world: Empirical evidence from Nigeria. International Journal of Civil Engineering and Technology, Vol. 10, No.(2), pp. 2329-2347

[4] Allen, F. and Carletti, E. (2008). The Roles of Banks on Financial Systems. Oxford Handbook of Banking. Wharlon financials. 
[5] Isibor, A., Ojo, J. A. T., and Ikpefan, O. A. (2018). Does financial deregulation spur economic development in Nigeria? PeerReviewed Proceedings of the International Business Information Management Association Conference (31st IBIMA) held on 25 - 26 April 2018, Milan, Italy.

[6] Isibor, A., Ojo, J. A. T., and Ikpefan, O. A. (2018). A study of financial deepening and capital accumulation in Nigeria. Peer-Reviewed Proceedings of the International Business Information Management Association Conference (31st IBIMA) held on 25 - 26 April 2018, Milan, Italy.

[7] Isibor, A., Olokoyo, F. O., Arogundade, M., Osuma, G., and Ndigwe, C. (2018). Exchange rate management and sectoral output performance. Peer-Reviewed Proceedings of the International Business Information Management Association Conference (31st IBIMA) held on 25-26 April 2018, Milan, Italy.

[8] Kumbirai, M. and Webb, R. (20 10). A Financial Ratio Analysis of Commercial Bank Performance in South Africa. African Review of Economics and Finance, Vol.2, No. (1), pp. 30-53

[9]Olokoyo, F.O. (2011). Determinants of Commercial Banks Lending Behavior in Nigeria. International Journal of Financial Research, Vol. 2, No.(2), pp. 61-72

[10] Sanderson, O.(2013). Branch Versus SelfService: Striking the Banking Balance. Accessed on March 28, 2016, available at http://bankinnovation.net/2013/06/branch-vs-selfservice-striking-the-banking-balance/

\section{Creative Commons Attribution License 4.0 (Attribution 4.0 International, CC BY 4.0)}

This article is published under the terms of the Creative Commons Attribution License 4.0 https://creativecommons.org/licenses/by/4.0/deed.en_US 